\title{
Ady Endre egy szaváról (dancs)
}

1. Ez a cikk egy hosszabb - még nem befejezett - tanulmány melléktermékeként született. Révész Béla (1925: 86-7) Ady életéről, verseiről írva egy helyütt a következőket mondja:

\begin{abstract}
„Följegyzem itt Adyról azt is, hogy a bibliás könyveket sokszor elővette, különösen a zsoltárokat nagyon szerette, a régies magyar írásokat, ha kezeügyébe kerültek, elmerülten olvasgatta, történelmi, nyelvészkedő magyar folyóiratok érdemesebb számait megszerezte, és itt is, mély ösztönével, mindig megtalálta azt, amivel eszközeit pallérozni tudta. Rendkívüli hangszerét nyelvi készségét, sokszor gazdagították ezek az olvasmányok, ő maga is beszélt erről és emlékezem, hogy megörült egyszer, mennyire magyarázgatta nekem, hogy talált egy nagyszerü ősi szót, mely az ő szavai közé való, a Szilágyságban a nép még ma is használja. Olyasfélét jelent: ügyefogyott, balog, nem életrevaló. Verseiben föl is használta ezt a szót, egy helyütt így kerül elénk: »Gyülölöm dancs keleti fajtám. - Mely, hogy kifáradt, engemet adott...« Még leveleibe is bevitte ezt a szót, egy barátunkról írta hozzánk Párizsból: »Ilyen dancs ember nem élt még a földön.«"
\end{abstract}

Aztán megemlíti, hogy Ady magyar irodalmat, társadalmi, politikai lapokat, folyóiratokat is rendszeresen olvasott, a Huszadik Századot állandóan.

Ady Endre nyelvészeti érdeklődésével kapcsolatban még megjegyzem, hogy általában is igen nagy újság- és folyóirat-olvasó volt. Kovalovszky Miklós (1993: 807) az általa sajtó alá rendezett és kommentált Emlékezések Ady Endréröl címü sorozat ötödik kötetének tárgymutatójába ilyen címszót is felvett: „Ady újságszenvedélye, hírszomja". Bátyjáról írt könyvében Ady Lajos példaként a zilahi és a csucsai évekről szólva, a költő által olvasott nagyszámú újság, valamint folyóirat közül cím szerint is megemlít néhányat, és mindkétszer a Magyar Nyelvőrt is (Ady L. 1923: 34, 204). A zilahi években - különösen szünidőben - Ady Endre ennek a köteteit is tízes-tizenötös turnusokban hozta haza ,s olvasta már akkor is gyönge és miopsz szemével imbolygó gyertyaláng mellett féléjtszakákon keresztül’”. Amikor pedig később Ady Lajos a Tanáregyesületi Közlöny szerkesztője lett, és más folyóiratokból cserepéldányt kapott, Ady Érmindszentről vagy Csucsáról írt leveleiben kérte ezek elküldését. „Bandi mindezeket számon tartotta, s a Katholikus Szemlétől, a Magyar Nyelvőrön át a Földtani Közleményekig mindeniket olvasta.” Bóka László (1955: 48) Ady Lajosra hivatkozva szintén írja, hogy Ady rendszeresen olvasta többek között ,a Budapesti Szemlét, a Természettudományi Közlönyt, a Századokat és a Magyar Nyelvőrt. (Ez utóbbinak és a később megindult Magyar Nyelvnek holtáig rendszeres olvasója maradt s mint Arany János, ő is végig glosszázta a nyelvtudományi folyóiratok margóját.)" (Ez utóbbi közléseknek a forrását Bóka nem adja meg. ${ }^{1}$ )

A Nyugat 1910-as évfolyama 22., illetve 23. számának Figyelő rovatába Ady írt is két rövid nyelvészeti cikket. Az első Van-e magyar nyelv? címü, amelyben azt kifogásolja, hogy az újabb magyar nyelvhasználat alakítói (Kazinczyék) nem támasz-

1 Én pedig ezekben a ,vírusos” időkben ennek nem tudtam jobban utánajárni. 
kodtak kellő mértékben a népnyelvre. Igaz, mint írja, néhányan ,[...] Megpróbáltuk, kuruczék kezdték, Balassáék, Csokonai s jómagam is iparkodtam régi szavakat rálopni Erdélyből és Károlyi Gáspár magyartalan és mégis magyar bibliájából az újonnan jött fogalmakra”. Most már azonban késő. S megjegyzi: „Trattner és Károlyi egy 1839es füzete és egy gyönyörü magyar szógyüjtemény juttatta mindezt az eszünkbe, de első tervbéli gondunkat, hogy mintaképpen leírjunk ide száz-kétszáz gyönyörü külön magyar szót, elhessegettük" (Ady 1910d/1973:105; Jegyzetek: 363-4; lásd még: AEÖPM./1999). Persze, e kérdésben (is) középen van az igazság, a népnyelvre nyilván lehetett volna jobban támaszkodni, de a nyelvújitást csak ezáltal aligha lehetett volna véghez vinni. Ezt mutatja Ady második, a Szavak a patvarban címü cikke is (Ady 1910e/1973: 106-7; Jegyzetek: 367-8; AEÖPM./1999), amelyben konkrét példákkal óhajtotta megvilágítani, pótolni az előző cikkben mondottakat. Azt írja például, hogy a magyar nyelvet ,úgy megtipálták, ami megint tépászást jelent, hogy ma már a kokottra se igen kerül más szavunk, mint - kokott. Pedig tisztelet a régi és mai magyar nőnek, kevés nyelv tudta többféleképpen nevezni és osztályozni a szerelemhivatású nőt, mint a magyar. A szép cemende szót például szívből sajnálom, mert még a szingyulánál is kedvesebben öleli át a szóbeli fehérnép fogalmát és mivoltát. De nagyon beleándorodni nem akarok a dologba [,] csak néhány példát hoztam föl egy a múltkor említett, kis magyar szógyüjteményből..”

2. Magam sem óhajtok itt különösebben beleándorodni ('belekeveredni') az Adycikkek tárgyalásába. Többek közt azért tértem ki rájuk, mert a szakirodalom ugyan számontartja őket, az idézett kritikai kiadás jegyzetei (is) például megállapítják, hogy a költő használta nyelvjárási szavak dunántúliak, de Ady forrásait (egy kis füzet és benne egy szógyüjtemény) nem sikerült megtalálniuk - nekem viszont igen. Ez Horváth Zsigmond ('Sigmond) A' Balaton-melléki-Tájszótár' kivonata címü tanulmánya a Tudományos Gyüjteményböl (Horváth 1839). ${ }^{2}$ Ugyanakkor megállapíthatjuk, hogy az Ady által említett népnyelvi szavak (és Horváth Zsigmond gyüjtésének egy jó része) csak (viszonylag) szükebb területen ismert, és a vonatkozó jelentésre sokszor a köznyelvben is van megfelelő szó. Tehát például a (ma már) ritka kokott '1. könynyủ erkölcsü, félvilági nő' 2. 'prostituált' szó (1. ÉKsz. $\left.{ }^{2}\right)$ tágabban véve akkor sem állt egyedül a maga nemében, amint Horváth tájszavainak a jelentésmegadásai is mutatják: „Czemende = lotyó, lustos, szóbeli fejér nép”; ,Szingyula = czemende, szajha, ringyó, kurva.” (A kokott szónak viszont szerintem más, kevésbé durva a hangulata, mint ezeknek, tehát nem lett volna szerencsés velük helyettesíteni. Az ÉrtSz. is 'kitartott félvilági nő' jelentésben veszi fel, és jelöli, hogy a szó elavulóban van. Az ÉKsz. hasonlóan: „kiv[eszöben lévő] Könnyű erkölcsü, félvilági nő”.) Adyt a cemende és a szingyula szavak hangzása foghatta meg. A TESz.-ba is felvett ismeretlen eredetü cemende nem is régi szó, 1751-től adatolt 'értéktelen, silány <ruházat>' jelentésben,

2 Horváth Zsigmond (1782-1845) evangélikus lelkész, esperes, a Magyar Tudományos Akadémia levelező tagja egyházi, földrajzi és más területeken publikált, és a Tsz.-hoz balatonmelléki tájszókat gyűjtött (lásd Szinnyei 4 [1896]: 1307). Említett munkájára és azoknak az Ady-cikkekhez való viszonyára itt külön és részletesebben nem térek ki, ezt majd máskor teszem meg. 
a 'ronda; erkölcstelen <nőszemély>' értelem pedig csak 1857-től. S bizonyára nem régi a szingyula sem, alapvető szótáraink közül csak a CzF.-ban és az MTsz.-ban van meg. A CzF. szingyola alakot közöl, és az értelmezése ez: „Túl a Dunán am. ringyó, kurva, szipirtyó. Az ily személyek csúf neveiben igen gazdag a népnyelv." A MTsz.-ban is 'ringyó' jelentésben csak dunántúli adatok vannak (a Tsz.-ból is), csupán Kunszentmártonból van egy előfordulás 'pongyola, léha (?)' értelemben.

Egyébként Ady nyelvi, nyelvészeti érdeklődésének középpontjában költői nyelvének kialakítása, azon belül elsősorban a szókincs állt. Ami a tájszavakat illeti, „Petri Mór, Ady zilahi magyartanára nyomán tudjuk, hogy Ady már ötödikes gimnazista korában részt vett tájszavak gyüjtésében, sőt hogy osztályának legszorgalmasabb, legkiválóbb gyüjtöje volt" (Ady 1910d/1973: Jegyzetek, 363-4). Bakó Elemér (1939) pedig fel is sorol néhány szót, amelyet Zolnai Gyula Ady költői újításának vélt, noha azok (föleg a partiumi, erdélyi) magyar népnyelvböl eredeztethetők: göth 'köhögés', istenel 'teremt', folyóka 'patakocska' (vö. 1757-től SzT. IV. is), lengeteg 'elviselt, elnyütt', lásd még SzT.VII. 1589-től 'könnyeden finom' (is). Gunda Béla (1934: 131) az Ady használta górál 'hajigál' tájszóhoz szólt hozzá. Ezt az ÉrtSz. és az ÉKsz. ${ }^{2}$ is tájszónak veszi, ami szerintem, legalábbis Debrecenben és környékén (ma), már regionális köznyelvi szó. Az ÚMTsz.-ban is Délkelet-Magyarországról és Erdélyből vannak rá adatok. Ide vehető Adynak $A$ Tisza-parton címü versében (1905) előforduló déli verö (táj. v. irod.)'verőfény, ragyogó napsütés' (vö. ÉKsz., ÉKsz. ${ }^{2}$ ) vagy a malom alja kifejezés is: „Gémes kút, malom alja, fokos | [...] A Tisza-parton mit keresek?” Filep 1980: 512, azaz a NéprLex. 3. szerint ,a malom és környéke a falusi, mezővárosi társadalom fö érintkezési helye volt (malomalja), itt tárgyalták meg a híreket, értesüléseket, a közösség hétköznapi problémáit" (512). „A malom alja régen olyan hely volt, ahol a gazdák őrletés közben megvitatták a falu dolgait, ezért Adynál valószínűleg az ostoba szócséplés, a szellemi tunyaság szimbóluma lett" (Erinna. Irodalmi Tudástár). S az is érdekes, hogy Kálnási Árpád (2019/3: 96) Debrecenben hasonló jelentésben mostanában még fel tudta gyüjteni ezt a szót (és ő is utal az Ady-versre).

Visszatérve a dancs melléknévre, ez Adynak az Egy májusi hajnalon címü versében szerepel, amely kötetben elöször az Új versekben (1906 február), önállóan, legelőször pedig 1904. május 12-én a Budapesti Naplóban (BN.) Párisi hajnal címmel jelent meg. Király István jelzi azonban, hogy a „kihívó dacú sor: „Gyülölöm dancs, keleti fajtám «", csak az Új versekben (a továbbiakban általában: ÚjV.) lévő szövegváltozatban tünt fel, „tükrözve, hogy a »legkoldusabb nomádot« körülfogó, mitikus tájból ekkor lett csak vétót jelentő, ellen-Magyarországgá, ellen-Budapestté, a Müvész-emigránst befogadó otthonná Párizs" (Király 1970: I, 231; vö. még Uő 1982: I, 248-9). A kritikai kiadás (Ady 1900-1906/1988: 144-6; Jegyzetek: 517, 521-2) szerint Ady a legelső, a BN.-beli közlést később több helyen módosította, sőt négy versszakkal meg is toldotta (21-36. sorok), és bizonnyal már 1905 elején, mert február 26-án a Szegedi Dugonics Társaság felolvasó ülésén, az Egy párisi hajnalon címü versét olvasta fel. S „legalábbis e felolvasó ülés alkalmából jelent meg a SzV-ben [Szeged és Vidéke, 1905. február 28. IV. évf. 51. sz. 2] először a költemény teljesebb szövege. [...] A költemény e teljesebb változatát véglegesítette - ki- 
sebb-nagyobb változtatásokkal - az ÚjV.-ben.” Mindezt az ÚjV. ${ }^{3}$ alapján a Koczkás Sándor gondozta kritikai kiadás jegyzeteire hivatkozva írom. Az Ady-versek legújabb és legpontosabb szövegkiadása azonban ma már a Láng József és Schweitzer Pál-féle (Ady I-II./1994), és magukat a szövegeket általában innen veszem át, illetve olykor ezek rövid itteni jegyzeteit is felhasználom.

A 18 versszakos 72 soros költeményt itt nyilván nem idézhetem, csak néhány versszakát, amely az egész versről így is képet ad, és a dancs szó versbeli jelentésének a pontosabb megállapításában is segíthet. A költemény Adynak egy hajnali harangzúgásos párizsi sétán támadt gondolatairól szól. Az 1., 3., 7., 8., 10. és az utolsó két (17., 18.) versszakát (az 1-4., 9-12., 25-32., 37-40., 65-72. sorokat) idézem.

Sugaras a fejem $\mathrm{s}$ az arcom,

Amerre járok, száll a csönd, riad,

Fölkopogom az alvó Párist,

Fényével elönt a hajnali nap. (1. vsz.)

$[\ldots]$

Ki vagyok? A Napisten papja,

Ki áldozik az éjszaka torán.

Egy vén harang megkondul. Zughatsz.

Én pap vagyok, de pogány pap, pogány. (3. vsz.)

$[\ldots]$

Szent Napkeletnek mártírja vagyok, (7. vsz., 25-28. sor; későbbi betoldás)

Aki enyhülést Nyugaton keres,

Táltosok átkos sarja talán.

Sápadt vagyok? Oh, fess pirosra, fess.

Gyülölöm dancs, keleti fajtám, (8. vsz., 29-32. sor; későbbi betoldás)

Mely, hogy kifáradt, engemet adott,

Ki sápadtan fut Napnyugatra,

Hogy ott imádja Urát, a Napot.

[...]

Keleti vérem ez a lomha,

Szomjúhozóan issza Nyugatot:

A Napisten legbúsabb papja,

Rég kiszórt, fáradt sugara vagyok.

[...]

Én is megyek, kóbor, pogány hős,

Új balga Don [Don Quijóte], modern, bolond lovag,

$\mathrm{Ki}$, mi van is, írtja, kiszórja

Önlelkéből az áldott álmokat. 
Sugaras a fejem $\mathrm{s}$ az arcom,

Zúg a harang, megyek lassan tovább:

Megáldozott a dús Párisnak

Kövein a legkoldusabb nomád.

A kérdés tehát most az, hogyan határozzuk meg a dancs keleti fajta jelzős szerkezet versbeli jelentését. Ebben Ady maga van segítségünkre, mert 1906. április 9-én még a BN. munkatársaként szerkesztöi üzenetben válaszol egy Celldömölk jelszóval beküldött, a dancs szóról érdeklődő kérdésre. Az olvasó nyilván az ÚjV.-ben találkozott vele, amely elöször 1906. február elején jelent meg (lásd pl. Ady I./1994: 619). Ady Lajos (1923: 114) téved, amikor ezt 1906 májusára teszi. A költő válasza a következő: „A dancs szó már Erdélyben él leginkább, de Magyarország sok vidékén is használják azonban. Az irodalmi használatból azonban ez az ősi, gazdag értelmủ szép szó kikopott. Csak sok más jelzővel helyettesíthetjük: könnyelmü, tunya, szennyes, semmiházi" (Ady 1906/1968: 197; AEÖPM./1999).

Az újabb kérdés pedig immár: a dancs szónak melyik jelentését válasszuk az Ady által felsoroltak közül? Ehhez a keleti fajta megnevezés értelmezésén keresztül vezethet az út. Még ha abba a bonyolult és pontosan nehezen megválaszolható kérdésbe, mit ért Ady azon, hogy népe, nemzete keleti fajta, és mit ért magyarságon, csak részben megyek is bele. 1982-es Ady-monográfiájában például Király István erősen marxista - és szerintem (is) differenciálandó - ideológiai megközelítéssel hosszabban ír e „keletiségről” (1982: I, 239-63).

Az ősi, keleti eredet, a környezettől eltérő másság, büszkeség forrása is. Ugyanakkor Adynál (is) a „magyar ugar” kemény kritikája a fejlettebb, polgárosultabb és demokratikusabb Nyugat felé való irányulás szükségességét is jelentette, ami a társadalmi, politikai kihívásokra gyorsabb, erőteljesebb, eredményesebb választ kívánt volna. Nem pedig egyfajta lomha, tunya magatartást, amelyet több hasonló - és más, jó vagy rossz tulajdonság mellett - a magyar irodalmi hagyományban (is), az úgynevezett „keletiséghez”, illetve a magyarsághoz kötöttek. Minderre álljon itt néhány magyar irodalmi idézet: ${ }^{3}$ Kölcsey: „Büszke Magyar vagyok én, keleten nőtt törzsöke fámnak; | Nyúgoti ég forró kebelem' nem tette hideggé;” [...] ([Kölcsey], 1831; eredetileg cím nélküli töredék); Vörösmarty: „Néz nyúgatra, borús szemmel, néz vissza keletre | A magyar, elszakadott testvértelen ága nemének" (Zrínyi, 1828); Ady: „Vagyok fény-ember ködbe bújva, | Vagyok veszteglő akarat” (Vizió a lápon, $1903^{4}$ ), ,Száradjon ki az iharfa, | A büszke fa, a magyar fa, | Amely engem gyökerével, | Bever, lehúz, ideláncol” (Ihar a tölgyek közt, 1905), „Mi mindig mindenről elkésünk, | Mi biztosan messziről jövünk | Fáradt szomorú a lépésünk, | Mi mindig mindenről elkésünk” (Akik mindig elkésnek, 1907), „Ös Napkelet olyannak álmodta, | Amilyen én vagyok : | Hősnek, borusnak, büszke szertelennek, [...]" (Én nem vagyok magyar?,

3 Ezek közül egy-kettő Királynál (1982, I: passim) szintén megvan.

4 Ady I-II/1994 alapján itt és a későbbiekben is az első közlés évszámát adom meg, akkor is, ha a vers első, kötetben való megjelenése későbbi (pl. itt 1906 az ÚjV.-ben). 
1907), „, „Bibor-palástban jött Keletről | A rímek ősi hajnalán. [...] Szent Kelet vesztett boldogsága, | Ez a gyalázatos jelen” (Az ős Kaján, 1907), „Fáradt akarók hada ez” (A kürtösök szava, 1908), „Cigány-népek langy-szívü sihederje” (Nekünk Mohács kell, 1908), „Mindig elvágyik s nem menekülhet, | Magyar vágyakkal, melyek elülnek | $\mathrm{S}$ fölhorgadnak megint. || Tied vagyok én nagy haragomban, | Nagy hütelenségben, szerelmes gondban | Szomorúan magyar” (A föl-földobott kő, 1909), „Ösi nép vagy és jöttment” (Gözösröl az Alföld, 1910), „Rongyolt és csaknem reménytelen fajtának tartom a magyart, pláne, hogy demokratizáló forradalmába beleordított, tiport a nagy kultúrájú rontás, a háború” (S ha Erdélyt elveszik?, Ady 1912), „Mi nagy szépségünknek | Sohase volt ismerője | És merője, | Mert a magyar mindig dőre. || [...] Az Isten talán megóvja, | Leszek jó, bús siratója, | Leszek fajtám takarója” (A fajtám takarója, 1915), „Csodálatos, babonás, bús magyarság | Szeretlek” (Hadd szenvednék [érte], 1916), „Rossz, drága fajta, [...] A Sors, a sorsa | Bünben vészben és bennem harsog.” (A fajtám sorsa, 1917).

Juhász Gyula Ady Új versek címü kötetéröl írja: „Verseiben van valami napkeleti melódia, szín, fény, erő és szilajság, valami napimádó rajongás, valami turáni ösború" (Juhász 1905 [!] dec.: 169-70; az Új század 1905. decemberi száma nyilván kissé késve jelent meg). Az ő Magyar nyár 1918 címü versében pedig ezt olvassuk: „Fülledt a csönd, mint ha üres a kaptár, | Keleti lustán szunnyad a magyar nyár. || Mi lesz, ha egyszer szikrát vet a szalma, | És föllángol e táj, e néma, lomha?" (Magyar nyár, 1918). S Móricz Zsigmond, amikor a Kelet Népének a szerkesztését átvette, programadó cikkében is ír a keletiségről. Ebből röviden idézek: „Széchenyi láng lobbanással világított rá a nagy titokra: Kelet népe vagyunk. [Bekezdés] Igen: keleti a tüzünk és a hamvadásunk. Keleti a lelkesedésünk mindenért, amit szépnek tartunk, jónak vélünk s keleti a közönyünk, amellyel hagyjuk elmúlni a szépet és elaludni a jót. Keleti a bölcsességünk, amely mindent megért s megmagyaráz és keleti a közönyünk, amely előtt lóhalálban vágtat el a siker. Keleti a hősiségünk, mellyel folyton nagy fába vágjuk a fejszénket s keleti a tunyaságunk, amely miatt engedjük, hogy szorgalmasok, ügyesek fát vágjanak a hátunkon” (Móricz 1939: [1]).

Persze más kérdés, mennyire használjuk ma a magyarsággal kapcsolatban (amely legtöbb más néphez hasonlóan folyamatosan keveredett) a keletiség és az ősiség fo-

5 A BN.-ban jelent meg először 1907. január 6-án, majd az Új versek (1906) II. kiadásában Ki a magyar? címmel. „A versnek a svábokból jött magyarokat emlegető utolsó előtti sora [(,,.. Svábokból jött magyaroknak | Én nem vagyok magyar?”) - A. M. F.] a Vér és arany [1907. dec. - A. M. F.] 4. kiadásában szerepel először. A sor beiktatása minden valószínúség szerint összefüggött azzal a hajszával, amit a sváb származású Rákosi Jenő folytatott Ady ellen 19151916-ban" (Ady I./1994: 632). Ady tudvalevőleg a népek, nemzetiségek egyenjogúságának volt a híve, és egyébként sem származás szerint értékelt. Lásd pl. a Magyar jakobinus dala címü versét. Egy nemzetiségi származású, de magát magyarnak tartó embert pedig nyilván a magyar nemzet tagjának tartott.

6 Ady az 1912-ben kitört első Balkán-háborúra gondolt (Montenegró, Bulgária, Szerbia, Görögország felszabadító harca Törökország ellen). Európa-szerte tartottak e konfliktus világméretü kiszélesedésétől. A nagyhatalmak, köztük az Osztrák-Magyar Monarchia intenzív katonai felkészülésbe kezdett, és ezzel párhuzamosan több kísérlet történt a demokratikus jogok korlátozására, az ellenzék letörésére (lásd Ady 1912: 564 [Jegyzetek]). 
galmait s magát a fajta megjelölést; illetve, ha megszorításokkal meg is nevezhetünk bizonyos nemzeti vonásokat, viselkedési mintákat, ${ }^{7}$ azokat csak történeti kontextusban tehetjük, körültekintően vizsgálhatjuk, egyénekre pedig automatikusan nyilván nem alkalmazhatjuk.

Mindenesetre látható, hogy dancs szavunknak az Ady által fentebb felsorolt jelentései közül az Egy párisi hajnalon címü versbe leginkább a 'tunya' illik. Ezt maga a költemény szövege is erősíti. „A dancs keleti fajtám”-mal rokonítható a „Keleti vérem, ez a lomha” sor és távolabbról például „A Napisten legbúsabb papja, | Rég kiszórt, fáradt sugara vagyok" sorok, valamint a Don Quijótére való utalás is. Sőt egy korábbi Ady-idézet is. A költő a Nagyváradi Naplóban (NN.) 1902. január 31-én Menjünk vissza Ázsiába címü vezércikkében szól arról, hogy a magyar parlamentben Vázsonyi Vilmos demokrata képviselő a felszólalását nem tudta elmondani: „A keleti nomád lomhasága lázadt fel ugye, hogy semmisítsük meg azt az embert még Krímiából velünk hozott eszközökkel, mert tanulni, tudni, s az ö fegyvereivel állni vele szemben nem tudunk" - írja többek között (Ady1902/1997: 183. sz., AEÖPM./1999). ${ }^{8}$ Summázva: magam a dancs szónak az Ady-versben a 'lomha' (és/ vagy a 'tunya') jelentésével számolnék. Persze, írt ő a „keletiségről”, a magyarságról - fentebb részben láthattuk is - más, akár egymásnak ellentmondó jelzőkkel is, de itt most a tárgyalt versről van szó. - Mindenesetre, nem értek egyet a ÉrtSz.-val, amely a (tájnyelvinek jelölt) szónak a 'szennyes, szurtos, ronda, undok' jelentését tartva számon, erre egyetlen példaként Ady „Gyülölöm dancs, keleti fajtám” verssorát hozza.

3. Azt a Révész által - pontosabb adatok nélkül - említett levelet, amelyben Ady szintén használja a dancs szót, a költő 1910. március 11-én vagy 18-án írta Révész Bélának, és többek között Reinitz Béláról is érdeklődik: „Írj, kérlek Reinitzről is. Ez az állat talán révbe jutott végre. De mi van a nótáival? Ilyen dancs ember nem élt még a földön" (Ady 1910b; Scheiber, Zsoldos: 1910/1965: 43). Az utóbbi helyen a közzétevök a MTsz. alapján 'ronda, undok'-nak értelmezik a dancs szót,

7 Egy más témájú (A Szózat nyelvtörténeti elemzéséhez címü) cikkemből, a Magyar történeti szövegtárból véve (lásd a nagyszerü szó alatt) hozok egy idézetet például a magyarokról nem egyszer mondott „,szalmaláng-lelkesedésre”. Fáy András a Bélteky-ház (1832) című regényében írja: „Gyanítnom kell, felele a generál, hogy itt magyar nemzetünknek lelki bélyege áll leginkább ellent. Köz vádjok az ellene az idegeneknek, mit históriánk is igazolni látszatik, hogy a magyar, nem borzad ugyan az óriási tettektől, nagyszerü ['nagyszabású, ? kiváló'] munkáktól, csakhogy azok tartósak és hosszas kitürésüek ne legyenek. Első láng, első lobbanás határoz nála, úgy csatáiban, mint polgári kezdeményeiben, és mindennemü vállalataiban: ekkor ritka erőteljt fejt ki, de azután pihenni siet” (A. Molnár: 2017: 105). Avagy egy más szempontra lásd Ady: A civódó magyar címü versét és verscímét (1910).

8 Vázsonyi egy debreceni, a párbaj kérdéséről szóló és ezzel kapcsolatban az iskolai történelemtanítás módját kritikusan említő előadásában a kultúrbestia szót is használta. „A képviselőház ülésén Hortoványi József ellenzéki képviselő költségvetési beszéde során kitért Vázsonyi debreceni előadására, bár Vázsonyit néven nem nevezte. Vázsonyi [...] személyes kérdésben felszólalt, hogy megmagyarázza a kultúrbestia kifejezés értelmét, de a függetlenségi és néppárti képviselők [...] óriási botrányba fullasztották Vázsonyi felszólalását, nem engedték szóhoz jutni” (i. h.; jegyzetek). 
az Ady által fentebb említettek közül pedig legjobban a 'semmiházi' jelentés illhetne ide. Reinitz Béla (1878-1943) zeneszerző, zenekritikus számos Ady-verset zenésített meg (pl. Új vizeken járok, Kató a misén, Héja-nász az avaron, Örizem a szemedet; néhány a YouTube-on is hallható), ami akkor jelentősen hozzájárult a költő népszerüsítéséhez is. Ezek általában az Andrássy úti Helvetia kávéházban hangzottak el először. S Ady és Reinitz a Nyugat által szervezett több vidéki irodalmi esten is együtt szerepeltek, a sikerben pedig a Reinitz-daloknak is nagy része volt. Ady Lajos (1923: 135) írja, hogy nem lévén zeneértő, Reinitz Ady-dalainak az abszolút zenei értékéről nem tud nyilatkozni. „Egyet azonban tudok: rengeteg azoknak az Ady-híveknek a száma, akik Reinitzon, a muzsikuson át jutottak el Ady Endre, a költő megértéséhez, s élvezéséhez. S tudom azt, hogy Bandi szerint: »Reinitz a verseim burkolt leglelkét fogta meg«.” Amikor azonban Ady a Royal hangversenyteremben elöször mutatkozott be nagyobb budapesti közönség előtt (1909. nov. 27-én), felolvasásai mellett a versei váratlanul nem Reinitz Béla, hanem egy vagyonos (és az estet is finanszírozó) amatőr muzsikus, Beretvás Hugó megzenésítésében és zongorakíséretével, valamint Környei Béla jeles operaénekes előadásában hangzottak el. Ezzel mélyen megsértette Reinitzet (lásd pl. Ady L. 1923: 135-6; Scheiber-Zsoldos 1965: 42; Ady 1910/1973a: 20-4; Jegyzetek: 252-73; AEÖPM./1999). Reinitz - amint Bölöni visszaemlékezett - a Meteor kávéházban a mellőzését olyan indulatosan kérte számon a költőn, hogy Ady a vita végére teljesen összeomlott, sírógörcsös rohamot kapott (erről s Ady és Reinitz kapcsolatáról lásd Ady 1910/1973a: 252-73; 330-1; Flórián-Vajda 1978: 28-51; Kelemen Éva 2013). A barátság megszűnt köztük. Nyilván ez a vita volt az oka, hogy a visszaemlékezés indulatától inspirálva levelében Ady (1910b) Reinitzet dancs 'semmiházi'(? 'undok, ronda') embernek nevezte. Később azonban ezt megbánta, megkövette, Renitz Ady-dalok. Első sorozat. Húsz dal. (Budapest, 1910) című kiadványáról igen elismerő rövid ismertetést írt. Többek között azt mondván, hogy „,Reinitz zsenialitása valahol a zseniális fordítóé és a zseniális interpretálóé között lehet” (Ady 1910/1973c: 71; AEÖPM/1999). Ez eredetileg a Révész Béla szerkesztette rövid életü Renaissance társadalmi folyóirat I/6-os számában ankét formájában jelent meg, amelynek a Kritika rovatába Révész több recenziót is közölt az Ady-dalok megzenésítéseiröl, így akarva Reinitznek elégtételt szolgáltatni. A Reinitz-kiadvány megjelenése alkalmából szervezett ankét keretében Ignotus, Kabos Ede, Kern Aurél, Nagy Endre, Schöpflin Aladár és Vészi József is igen elismerően írt Reinitz megzenésítéseiről, és ez ,együtt mintegy kiállást is jelentettek Reinitz mellett a hivatalos zenekritika ítéletével szemben" (Ady 1910/1973c: [Jegyzet] 330-1, vö. még: [Jegyzet] 252-73). De például Csáth Géza is Reinitz Béla és Farkas Ödön, valamint Beretvás Hugó megzenésítéseiről írva, közülük egyértelmüen Reinitzet emeli ki, bár kritikai megjegyzései is vannak (Csáth 1910). Reinitz összesen több mint 130 Adyverset zenésített meg (többségük kiadatlan), egy részük már Ady halála után született (vö. Komlovszky 1993: 278). Az Ady-versek megzenésítései annak idején nagyobb jelentőségüek voltak, mint később vagy manapság.

Ami Adynál a dancs szó jelentését illeti, úgy gondolom tehát, hogy a költő kétféle értelemben használta. Az Egy párisi hajnalon címü versben 'lomha, tunya', a Révésznek írt levélben pedig 'semmiházi; undok, ronda' a jelentése. 
4. A dancs szó eredeti, illetve fő jelentéséről, jelentéseiről pontosabb felvilágosítást elsősorban nyilván szótáraink nyújtanak. Fentebb említettem már a MTsz. és a ÉrtSz. adatait. Ezekhez hozzátehetjük még például a következőket: CzF.: „dancs fn. és mn. [...] Erdélyben divatos szó, am. szenny, mocsok, szurtosság"; dancsos 'Szennyes, mocskos, tisztátalan, szurtos'; dancsosság 'mocskos, szennyes, szurtos, tisztátalan tulajdonság vagy állapot'; EtSz.: „1. dancs [erdélyi tájszó], MTsz.; első adat SzD. ${ }^{1} 18$ [...] alakv. doncs PP. $1801 \mathrm{~m}$. [...] 'mocskos, szennyes, ronda, undok' PP. $1801 \mathrm{~m}$. [...] 2. ? 'szenny, mocsok, tisztátalanság' SzD. ${ }^{1} 18 .$, SzD. ${ }^{2}$ [...] (a szó főnévi használatát a népnyelvből nem tudjuk igazolni). - Származékok: dancsos [...] 'szennyes, mocskos'; dancsosság, dancsság"; ÉKsz.: dancs 'mocskos, piszkos', ÚMTsz.: dancs 'piszkos, mocskos; [!] szaros'; dancsság 'piszkosság, mocskosság'; TESz. (vö. még EWUng.): dancs A) fn. 1.: 1771: 'tisztátalan személy; unreine Person'; 2. 1784: 'tisztátalanság; Unreinheit'; 3. 1865: 'szitok'; 4. 1940: '<csapatjátékban> az ellenfél valamely játékosa ellen elkövetett szabálytalanság; Foul, Regelverstoß'. B) mn. 1801'tisztátalan; unrein | mocskos; schmutzig'. Származékok: dancsos (1807) | dancsol (1953). A szóadatok mellé egy mondatbelit is idézek az ÚMTSz.-ból, amely a korábbi Nsz. (Nszt.) egy kéziratos tájszógyüjteményéből való (a címben helymegjelölés nélkül; de egyébként a másutt jelölt helyszínek mind erdélyiek): ,Jâj de dancs vagy te köjök! Hogy tudtad magad úgy összemocskolni?!"

A magyar nyelv nagyszótára (Nszt.) - a CzF., a ÉrtSz., a TESz., a ÉKsz., az ÚMTsz. megfelelő szócikkeire hivatkozva - és főleg nyilván saját anyagára és gyüjtésére alapozva fönévként a dancs szót (rég. átv. is) minősítéssel 'mocsok, szenny, piszok' jelentéssel veszi föl (I.1.), és három adatot hoz rá. Az első Baróti Szabó Dávid Kisded szótárából (1784) való: „,Dants [=] Dantsofág, tsúnyaság, sundaság (nem türheti a' galamb a' rút dantsofságot)." A harmadik Nyulassy Antal (Ignác) szerzetes, tanár Kátyololatok a nép életéből címü verseskötetéből (1865): „Káromolja a nagy Istent, Csúfot üz müvéből; Szentségtelen dántsokat küld A sut mély üréböl”. Az I.2.-es főnévi jelentés: „(kissé rég, Sp) <labdajátékokban, kül. labdarugásban:> az ellenfél játékosa ellen elkövetett durva lökés v. gáncsolás". Erre három adat van, de ezek most nem nagyon érdekelnek minket, mert késeiek: a szót egy nyelvújító pályázaton a fault megfelelöjének ajánlották, de nem honosodott meg. Az első, a Nemzeti Sport 1939-es évfolyamából való példa (dancsban) egyébként egy évvel korábbi, mint amit a TESz. és az EWUng. erre a jelentésre hoz. A II., melléknévi (rég v. nyj) 'mocskos, piszkos v. ápolatlan, rendetlen külsejü $<$ személy $>$, ill. valamivel beszennyezett $<$ dolog $>$ ' jelentésre a szótár az 1809 és az 1956 közötti időből öt példát hoz. Az első Simai Kristóf szerzetes, tanár, író Vég tagokra szedetett szótárából (1809) való: „Dants (sunda) Sordidus, turpis, indigestus.” A második a Vasárnapi Újság 1857-es évfolyamából: „A czigány nép rendesen dancs, nevezetesen vén asszonyaik $\mathrm{s}$ a férfiak. De a leányok szépek, barnák, magosak, tüzesek." S megemlíttetnek még a dancsol és a dancsos származékszók is.

A dancs szó jelentésváltozásait a TESz. a legkorábbról (1771-től) adatolható fönévi szófajú A) I.-el jelölt értelemből származtatja metonimikus, illetve metaforikus névátvitellel. Leegyszerüsítve: 'tisztátalan személy' (vö. 1771) $\rightarrow$ 'tisztátalan, mocskos' (vö. 1801). A példákban azonban sokszor nehéz egyértelmủen eldönteni a szófajt. 
A TESz. legkorábbi, fónévnek vett adatában is a szó szerintem melléknév is lehet. A John Locketól (vö. Some Thoughts concerning Education) Borosjenői gróf Székely Ádám által franciából fordított, A gyermekek neveléséről című, először Kolozsváron 1771-ben megjelent könyvböl való példamondat ugyanis a következő: ,a’ vásott és tüzről pattant gyermekből-is bolondot, dantsot tsinál”. S láttuk, a Nszt. II., melléknévi jelentésében is szerepel egy $<$ személy $>$, illetve $<$ dolog $>$ hozzáfüzés, tehát a melléknévi vagy főnévi szófaj attól is függ, beleértjük-e ezeket a jelentésbe, vagy nem. Az EtSz. pedig meg is jegyzi, hogy a népnyelvből a főnévi szófajra nincs adata. S látható, hogy több más szótárunk is csak melléknévi előfordulást hoz. Persze eredeti főnévi jelentés szintén lehetett, azért is, mert a szó - amit az EtSz. még ismeretlen eredetünek tart - egy főnév átvétele. A TESz. (és idézett szakirodalma) szerint a dancs [...] „Román eredetü; vö. rom. danci 'cigánygyerek, purdé'. Ennek forrása a cig. den $\check{c} i$ 'adj nekem valamit'. A jelentések közül [1. fentebb] az A) 1. a román szó 'cigánygyerek' jelentéséből jött létre azon az alapon, hogy a régi társadalomban a putrikban élő, kóborló cigánygyerekkel a tisztátalanság képzetét asszociálták. [...] melléknévként erdélyi nyelvjárási szó." Az oklevelekből való korábbi adatok (1478: Danch kees; 1602: Dancs személynév az adatok korai volta miatt aligha tartoznak ide, Melich szerint a nevekben Dancs a Domokos becéző alakja (EtSz.; vö. TESz., EWUng.).

A dancs szó szerepel Márton Gyula, Péntek János, Vöö István A magyar nyelvjárások román kölcsönszavai címü munkájában is (1977; RK.), amely nemcsak publikált adatokat, hanem (még nagyobb számban) kéziratosakat is felhasznált, köztük a kolozsvári egyetem magyar tanszékének kéziratos anyagát is. Kézikönyvükben a dancs melléknévi (nép) 1. 'undorítóan mocskos, ocsmányságokat beszélő (egyén)' jelentése áll legelöl számos szóadattal. A főnévi 'piszok, mocsok' jelentést egyedül Balassától idézik (hasonlóan a dancsos 'piszkos, mocskos'-t is). S van egy adat a 'bozót' jelentésre, valamint a dancsol 'korhelykedik'-re (Kisújszállás: MTsz.) és a dancsalkodik 'undorító dolgokkal foglalkozik, ocsmánykodik' származékra. A szó román eredetét szintén jelzik: „• r. danci cigányfiú gúnyneve (Scriban). [...]”. A magyar szókincs román elemeinek története címü monográfiájában Bakos Ferenc (1982: 101, 113, 254-55, 430) viszonylag részletesebben foglalkozik a dancs szóval. Megemlíti a jelentés pejorációs eltolódására hozott példái között: „,dancs 'szurtos, mocskos gyerek' < r. danci 'cigánygyerek' (a magyar szó körül - mindig rosszalló érelemben - átmenetileg eléggé árnyalt jelentések és szócsalád alakult ki)" (101). S azt is jelzi, hogy Erdélyen kívül a Tiszántúlról három megyéből adatolható (113). A szócikkek (kommentált) felsorolásakor pedig a 18. századtól előforduló, több megyében és az irodalmi nyelvben is fellelhető szóként a következő jelentésekkel, adatokkal mutatja be (rövidítve közlöm): I.1. 1771: ? 'szennyes, mocskos személy', 1827; 2. 1779-1864: 'szenny, mocsok', föleg dancsosság; 3. 1801: mn dancs, doncs 'szennyes, piszkos, ronda', 1807: dancs, dancsos. Ez a jelentés Erdély szerte elterjedt (vö. RK.). Ide még: dancsalkodik 'undorító dologgal foglalkozik' 4. mn 1830-1865: 'cinikus'; - dancsos, dancsoskodik, dáncsoskodik 'szitkozódik, mocskolódik'; dancsol 'korhelykedik'; 5. 1940-es évek: 'gáncs, fault'; - „II. < r. danci 'cigánygyerek, purdé'. Ez cigány eredetü. - A magyarba átkerült szó egyrészről erdélyi népnyelvi szó maradt, másrészről átmenetileg az írói nyelv divatszava (Kazinczy, Döbrentei stb.: NSz)., illetve az angol fault kérészéletü magyarítása. - TESz. (254-255).” A fogalomkörök szerinti csopor- 
tosításban pedig Bakos megjegyzi, hogy a külső megjelenésre, fizikai sajátosságokra vonatkozó 69 román szó (túlnyomórészt melléknév) között „komoly szociális értéke mindössze az átmenetileg az irodalmi nyelvbe, majd a sportnyelvbe is bekerült dancsnak, az erdélyi magyar köznyelvben elterjedt lunguj-nak ['hórihorgas ember'], továbbá az Erdély-szerte járatos szilimán-nak ['szerencsétlen, élhetetlen'] van" (431).

Benő Attila A kölcsönszó jelentésvilága. A román-magyar nyelvi érintkezés lexikai-szemantikai kérdései című mủvében (2004), amely példaanyagát elsősorban a RK. anyagából meríti, a dancs szót szintén idézi. Hasonló jelentéssel közli, mint a RK., azzal a különbséggel, hogy elhagyja a szójelentés végéről az egyén szót ölelő zárójelet (Benő: 2004: 87). Könyvének elméleti beágyazottságából következően is, egy példájában a konnotáció szempontjából a dancs jelentésváltozására szintén kitér. A 'cigány fiú' és a 'piszok, mocsok' jelentés közti kapcsolat úgy szemléltethető, hogy a közösség mentális képében a RK.-beli jelentésben megadott tulajdonságok halmazából (undorítóan mocskos, ocsmányságot beszélö) egy elem ('mocskos') „kezd szorosabb konnotatív viszonyba lépni az eredeti jelölttel, megteremtve a névátvitelhez szükséges motivációs alapot” (Benő: 2004: 106). S az RK. anyagánál maradva, bizonyára azt is föl lehet tenni, hogy az ott jelzett eredeti jelentésből konnotációval a 'mocskos, piszkos' értelem ugyancsak kialakulhatott. A fónévi és a melléknévi jelentés(ek) kölcsönös kapcsolatban is állhattak, és egyik is keletkezhetett a másikból (elvonás, képzés). S a 'mocsok, piszok' fönévi jelentés szintén, illetve egyik is alakulhatott a másikból (elvonás, képzés). Avagy közvetve vagy közvetlenül más, ritkább jelentések is létrejöhettek, amelyekben a konnotáció kevésbé világos és csak esetenkénti. Ilyen jelentésváltozásokra Benő (2004: 106-7) is hoz nem egy példát. S Bakos is jelzi, hogy a magyar dancs szó körül „átmenetileg eléggé árnyalt jelentések és szócsalád alakult ki” (1982: 101). - Azt, hogy a román (nép)nyelvben volt-e a danci szónak más jelentése, jelentésárnyalata is - ami a magyar átvétel jelentését, jelentéseit befolyásolhatta volna -, nem tudom, a románból való adatolhatóság korát sem, mint ahogy azt sem, vajon az átvett magyar szóban az első ismert adatok előtt nem történhetett-e (esetenkénti) jelentésváltozás.

Révész visszaemlékezéseiből láttuk, Ady csak később ismerkedett meg a dancs szóval. Lelkesen magyarázta, hogy talált egy, az ő szavai közé való nagyszerü ősi magyar szót, amelynek a költőtől hallott jelentéseit Révész, úgy húsz év múlva, emlékezetből sorolta föl ('ügyefogyott, balga, nem életre való'). Ady, bizonyára gyorsan készült, nem a legjobb stílusú szerkesztőségi üzenetében a felsorolt jelentések, jelentéskomponensek ('könnyelmű, tunya, szennyes, semmirekellö') közül a 'szennyes' vezethetö vissza közvetlenül a szótárainkban lévőkre, a 'semmirekellő' pedig könnyen származtatható, érthető a szótározott 'undok, ronda' jelentésből, de éppenséggel akár a többi adatoltból is (vö. a Révésznek írt levélben Reinitz említését). A BN.-ban az Ady megadta jelentések, jelentéskomponensek közül a 'tunya' és a 'könnyelmü' nincs benne a szótárainkban, de fentebb bő példaanyagon mutattam be, hogy a 'lomha', illetve a 'tunya' Adynál (is) a „keleti fajta” egyik tulajdonsága, tehát a dancs ilyen jelentéssel jól illik az Egy párisi hajnalon címü versbe. S nagyon is el tudok képzelni olyan beszédhelyzetet, amikor a 'cigánygyerek, cigányfiú, purdé' és a hozzájuk kapcsolt említett tulajdonságok egyik (további) konnotációja a 'lomha, tunya' (sőt akár a 'könnyelmü'). De még az is meglehet, hogy adott esetben Ady nem egészen pontosan 
értelmezte a szóhasználatot. Az átadó román szót pedig nyilvánvalóan nem ismerte. (Ady - bár szülöhelyén, Érmindszenten már akkor is többségben voltak a románok nem tudott jól románul, ,inkább csak értett, mint beszélt; erre nemigen volt akkor szüksége” [lásd Kovalovszky 1974: 656]). Miután viszont megtalálta és „magáévá tette" ezt a szót, több és részben szótárakból is igazolható vagy azokhoz közeli jelentésben tartotta számon. S a (18. század végétől adatolható) népi és erdélyi használatban tévesen ősi magyar eredetet érzett, és a szót némi költői szabadsággal is alkalmazta. A dancsnak ugyan például a CzF.-ban vagy a MTsz.-ban már utánanézhetett volna - de ezt ne várjuk el tőle. A szótáraink révén adatolható, és Ady által is említett 'szennyes' jelentést az Egy párisi hajnalon című versébe azért sem tartom odaillőnek, mert - bár pusztán szótanilag és grammatikailag nézve a dancs szót tartalmazó mondat („Gyülölöm dancs, keleti fajtám, | Mely, hogy kifáradt, engemet adott”) - ezt megengedné, a vers egész mondandója, tartalma, hangulata aligha.

Király István a „keletiség” jelenségét Adynál vizsgálva az Egy párisi hajnalont a Nyugati hübrisz és dackeletiség (1904) alcím alá sorolja. A versben eredetileg a romantikus és dacos keletiség áll szemben a Nyugattal (lásd még Földessy 1962: 37-8). Az említett, a dancs szót tartalmazó sorok betoldása (1905) után viszont nyilván a Müvészi-költơi keletiség (1905-1908) korszakához is kötik szálak. S egyébként (merev) kategóriáiról Király (1982 I.: 247-63) maga is mondja, hogy azok egyes jellemzői más időszakokban is megjelenhetnek. Mindenesetre Ady - még ha „fajtáját”, javító szándékkal, többször keményen bírálta, elmarasztalta is -, azt nyilván nem mocskosnak, szennyesnek, piszkosnak, undoknak, rondának tartotta.

Adynál a dancs szó jelentéséről, használatáról tehát a főleg lexikológiai, szemantikai, etimológiai, vizsgálat oldaláról is hasonló eredményre juthatunk, mint fentebb az elsősorban a verselemzést, a stilisztikát, a frazeológiát illető vizsgálatban. Ezt az Egy párisi hajnalon címü vers elemzésekor is jó figyelembe venni és nem automatikusan a ÉrtSz. értelmezéséhez fordulni.

\section{SZAKIRODALOM ${ }^{9}$}

Ady Endre [1897-1918]/1999. Összes prózai müve. 1-11. köt. [AEÖPM.]. Forrás: Ady Endre összes művei CD-ROM (Arcanum Adatbázis Kft., 1999). Kiadja az Arcanum Adatbázis Kft. és a FolioNET Kft. HTML. Szerk.: Szabolcsi József. URL: mek.oszk.hu/00500/00583/ $\mathrm{html} /{ }^{10}$

9 A szakirodalmi munkák idézeteiben szereplő más művek (pontos) bibliográfiai adatait itt csak akkor adom meg, ha arra szükség mutatkozik. Ugyanez áll az egyes versekre, verscímekre is.

${ }^{10}$ A kiadó a címleíráshoz, annak részeként a következő megjegyzést füzi: „A CD-ROM alapjául az Akadémiai Kiadó „Ady Endre összes prózai művei c. tizenegy kötetes kiadása szolgált. A prózai müvek kritikai kiadása 1955 és 1982 között jelent meg. Az első két kötetet 1990-ben, ill.1997-ben átdolgozva újra kiadták, ezeknél az új kiadás anyagát használtuk. A jegyzetapparátust nem dolgoztuk fel. A cikkek, tanulmányok megjelenésük sorrendjében, a használt forrás kötetszerkezetét követve szerepelnek az adatbázisban.” E bibliográfiai tétel általam alkalmazott [1897/1918]/1999 időjelöléséből szövegközben csak az /1999-et használtam (egyes alábbi bibliográfiai adatokra való pontosabb utalás után). 
Ady Endre 1902. Menjünk vissza Ázsiába. Nagyváradi Napló 1902. január 31. In: Ady Endre összes prózai müvei. [AEÖPM.] Újságcikkek, tanulmányok II. 1901. május - 1902. február. Szerk. Koczkás Sándor. Akadémia-Argumentum, Budapest, 1997. 183.

Ady Endre 1904 (1905)/1988. Egy párisi hajnalon. Budapesti Napló 1904. május 12. In: Ady Endre összes versei II. 1900-1906. jan. 7. S. a. r. Koczkás Sándor. Akadémiai Kiadó, Budapest, 1988. 144-6; Jegyzetek: 517-22.

Ady Endre 1906. Celldömölk. Budapesti Napló április 9. In: Ady Endre összes prózai müvei [AEÖPM.] Újságcikkek, tanulmányok. VII. Szerkesztői üzenetek. S. a. r. Kispéter András és Varga József. Akadémiai Kiadó, Budapest, 1968. 198.

Ady Endre 1910. január - 1912. december. Ady Endre összes prózai müvei. [AEÖPM.] Újságcikkek, tanulmányok X. S. a. r. Láng József és Vezér Erzsébet. Akadémiai Kiadó, Budapest, 1973.

Ady Endre 1910a. Poéta és publikum. Huszadik Század 1910. január-február. L. in: AEÖPM. X. 20-4; Jegyzetek: 252-73.

Ady Endre 1910b. Révész Bélának [Páris, 1910. március 11.]. In: Ady Endre levelei II. 19091913. Szerk., a szöveget gondozta Belia György. Szépirodalmi Kiadó, Budapest, 1983. 83-4. L. még Scheiber-Zsoldos 1965: 42-3.

Ady Endre 1910c. Ady-dalok. Renaissance 1910. júl. 25. 555-6. L. in: AEÖPM. X. 71-2; Jegyzetek: $252-73 ; 330-1$.

Ady Endre 1910d. Van-e magyar nyelv? Nyugat 1910. november 16. L. in: AEÖPM. X.103-5; Jegyzetek: $363-4$.

Ady Endre1910e. Szavak a patvarban. Nyugat 1910. december 1. L. in: AEÖPM. X. 106-7; Jegyzetek: 367-8.

Ady Endre 1912. S ha Erdélyt elveszik? Huszadik Század 1912. nov. — dec. 737-8. L. in: AEÖPM. X. 206-9; Jegyzetek: 563-5.

Ady Endre I-II. /1994. Ady Endre összes versei. I-II. kötet. A szöveget gondozta és a jegyzeteket összeállította Láng József és Schweitzer Pál. Javított szövegü kiadás. Osiris-Századvég, Budapest, 1994.

Ady Lajos 1923. Ady Endre. Amicus, Budapest.

AEÖPM. = Ady Endre összes prózai műve. I-XI. köt. (L. fentebb az idézett kötetcímeknél, valamint a legelső bibliográfiai tételnél.)

Bakó Elemér 1939. Ady és a népnyelv. Magyar Nyelv 35: 39-40.

Bakos Ferenc 1982. A magyar szókészlet román elemeinek története. Akadémiai Kiadó, Budapest.

Balassa = Balassa József: A magyar nyelv szótára I-II. Grill Károly Könyvkiadó, Budapest, 1940.

Benő Attila 2004. A kölcsönszó jelentésvilága. A román-magyar nyelvi érintkezés lexikai-szemantikai kérdései. Erdélyi Múzeum Egyesület, Kolozsvár. (Erdélyi Tudományos Füzetek 246.) https://doi.org/10.36240/etf-246

BN. = Budapesti Napló. [Magyar időszaki lap.] Budapest, 1896-1918.

Bóka László 1955. Ady Endre pályakezdése. Bevezetés az Ady-kérdésbe. Akadémiai Kiadó, Budapest.

Csáth Géza 1910. Reinitz Béla és Farkas Ödön Ady-dalai. Nyugat 1910: II/17. 1231-3; epa. oszk.hu/00000/00022/nyugat.htm (megtekintve: 2020. 12. 07).

CzF. = Czuczor Gergely - Fogarasi János: A magyar nyelv szótára I-VI. Emich Gusztáv -Athenaeum, Pest [később Budapest], 1862-1874.

ÉKsz. = Magyar értelmező kéziszótár. Szerk. Juhász József et al. Akadémiai Kiadó, Budapest, 1972. 
ÉKsz. ${ }^{2}=$ Magyar értelmezö kéziszótár. Második, átdolgozott kiadás. Főszerk. Pusztai Ferenc. Akadémiai Kiadó, Budapest, 2003.

Erinna Irodalmi Tudástár. Ady Endre: A Tisza-parton (elemzés). (2019. 09. 18). URL.: erinna. verselemzes.hu/ady-endre-a-tisza-parton-elemzes/(megtekintve: 2020. 12. 07.).

EtSz. $=$ Gombocz Zoltán - Melich János: Magyar Etymologiai Szótár. I. köt. I-X. füzet, II. köt. XI-XVII. füzet. Magyar Tudományos Akadémia, Budapest, 1914-1944.

ÉrtSz. = A magyar nyelv értelmező szótára I-VII. [Főszerk. Bárczi Géza és Országh László]. Akadémiai Kiadó, 1959-1962.

EWUng = Etymologisches Wörterbuch des Ungarischen . Band I-II. Hg. Loránd Benkö. Akadémiai Kiadó, Budapest, 1993, 1994.

Filep Antal 1980. Malom. Lásd in: NéprLex. III. 510-13.

Flórián László - Vajda János 1978. Reinitz Béla. Zenemúkiadó, Budapest, 1978.

Földessy Gyula 1962. Ady minden titkai. Magvető Könyvkiadó, Budapest.

Gunda Béla 1934. Górált fénycsodák. Magyar Nyelvőr. 63: 131.

Horváth 'Sigmond [Zsigmond] 1839. A' Balaton-melléki Tájszótár kivonata. Tudományos Gyüjtemény 1839. XII ${ }^{\text {dik }}$ kötet. 23dik esztendei Folyamat. Trattner - Károlyi tulajdona, Pesten. [3] -61 .

Juhász Gyula 1905. Ady Endre új versei. Az Új Század, 1905. december. http://hu.wikisource. org/wiki/Ady_Endre_új_versei (megtekintve: 2020.12.7).

Kálnási Árpád 2019. A debreceni civis élet lexikona. 1-4. köt. Méliusz Juhász Péter Könyvtár, Debrecen (Debreceni Értéktár Könyvek).

Kelemen Éva 2013. Aki megzenésitett több mint száz Ady-verset [Reinitz Béláról]. URL: nemzetikonyvtar.blog.hu/2013/11/15/aki_megzenesitett_több_mint_szaz_ady-verset(megtekintve: 2020. 12. 8.)

Király István 1970. Ady Endre. I-II. köt. Magvető Kiadó, Budapest.

Király István 1982. Intés az örzőkhöz. Ady Endre költészete az első világháború éveiben. 19141918. I-II. köt. Szépirodalmi Könyvkiadó, Budapest.

Kovalovszky Miklós (gyűjtötte, s. a. r., magyarázatokkal kiegészítette) 1974, 1993. Emlékezések Ady Endréröl. II. köt., V. köt. Akadémiai Kiadó, Budapest.

Magyar történeti szövegtár. Lásd:www.nytud.hu/cgi-bin/pat3h.cgi (megtekintve: 2020.10.10.)

Márton Gyula - Péntek János - Vöö István 1977. A magyar nyelvjárások román kölcsönszavai. Kriterion Könyvkiadó, Bukarest.

A. Molnár Ferenc 2017. A Szózat nyelvtörténeti elemzéséhez. In: Szalisznyó Lilla (szerk.): Tiltva, türve, imádkozva, énekelve. Tanulmányok a Szózatról. Reciti, Budapest, 79-115.

Móricz Zsigmond 1939. Kelet népe. Kelet Népe. V. évfolyam 11. szám. Budapest, 1939. december 15. Lásd még in: Móricz Zsigmond irodalmi munkássága. Bibliográfia. Összeáll. Kozocsa Sándor. Mủvelt Nép Könyvkiadó, Budapest, 1952. VIII. (a 80. és a 81. lap közötti faximile) is.

MTsz. = Magyar tájszótár I-II. Szerk. Szinnyei József. Hornyánszky, Budapest, 1893-1896, 1897-1901.

NéprLex. III. = Magyar Néprajzi Lexikon. III. köt. Főszerk. Ortutay Gyula. Akadémiai Kiadó, Budapest, 1980.

NN. = Nagyváradi Napló. 1898. október 1. - 1934. január 4. között megjelent politikai napilap.

NSz. = Az Akadémiai Nagyszótár gyüjtéséböl. Kézirat.

Nszt. V. = A magyar nyelv nagyszótára. V. köt. Főszerk. Ittzés Nóra. MTA Nyelvtudományi Intézet, Budapest, 2013. URL: nagyszotar.nytud.hu/index.html (megtekintve: 2020. 04.23).

PP. 1801. = Pápai Páriz Ferenc: Dictionarium Latino-Hungaricum/Dictionarium UngaroLatino-Germanicum. Martini Hochmeister et Mich. Landerer, Nagyszeben-Pozsony. 
Renaissance $=$ Politikai-társadalmi-művészeti és közgazdasági folyóirat (Budapest, 19101911).

Révész Béla 1925. Ady Endre életéröl, verseiről, jelleméről. Kiegészített második kiadás. Athenaeum, Budapest.

RK. = Román kölcsönszavak. Lásd Márton-Péntek-Vöő 1977.

Scheiber Sándor, Zsoldos Jenő 1965. Ady Endre levelei Révész Bélához. Acta Historiae Litterarum Hungaricarum 5: 35-45. URL: http://acta.bibli.u-szeged.hu/id/eprint/846

$\mathrm{SzD}^{1}$ = Baróti Szabó Dávid: Kisded Szó-Tár, melly A' ritkább Magyar szókat az A.B.C. rendi szerént emlékeztetö versekbenn elö-adja. Kassán, 1784.

$\mathrm{SzD}^{2}=$ I. m. (1. fentebb). Második ki-adás, meg-bővítve. Kassán, 1792.

Szinnyei IV. = Szinnyei József: Magyar irók élete és munkái. IV. köt. Hornyánszky, Budapest, 1896. Reprint: Budapest, 1980-1981.

SzT. IV. = Erdélyi magyar szótörténeti tár. IV. köt. Anyagát gyüjtötte és szerk. Szabó T. Attila. Szerkesztő-munkatársak P. Dombi Erzsébet et al. Kriterion Könyvkiadó, Bukarest, 1984. URL: mek.oszk.hu/08300/8370/pdf/index.html (megtekintve: 2020. 04. 25).

SzT. VII. = Erdélyi magyar szótörténeti tár. VII. köt. Anyagát gyüjtötte és szerk. † Szabó T. Attila. Szerkesztő-munkatársak: P. Bodrogi Katalin et al. Akadémiai Kiadó, Budapest; Kriterion Kiadó, Bukarest, 1995. URL: L. előbb.

TESz. = A magyar nyelv történeti-etimológiai szótára. I-III. köt. Főszerk. Benkő Loránd. Akadémiai Kiadó, Budapest, 1967-1976.

Tsz. = Magyar Tájszótár. Magyar Tudós Társaság, Buda, 1838.

ÚjV. = Ady Endre. Új versek. Pallas, Budapest, 1906.

ÚMTsz. = Új magyar tájszótár I-V. köt. Főszerk. B. Lőrinczy Éva. Akadémiai Kiadó, Budapest, 1979-2010.

\author{
A. Molnár Ferenc \\ professor emeritus \\ Miskolci Egyetem, Magyar Nyelvtudományi Tanszék \\ Debreceni Egyetem, Magyar Nyelvtudományi Tanszék \\ https://orcid.org/0000-0003-0869-3588
}

